\title{
Valorization of Briquettes Fuel Using Pinus spp. Sawdust from Five Regions of Mexico
}

\author{
María Alejandra Ramírez-Ramírez, ${ }^{\mathrm{a}}$ Artemio Carrillo-Parra, ${ }^{\mathrm{b}}$ Faustino Ruíz-Aquino, ${ }^{\mathrm{c}}$ \\ Luis Fernando Pintor-Ibarra, ${ }^{\mathrm{a}}$ Nicolás González-Ortega, ${ }^{\mathrm{a}}$ Rocio Orihuela-Equihua, ${ }^{\mathrm{a}}$ Noel \\ Carrillo-Ávila, ${ }^{\mathrm{d}}$ Concepción Luján-Álvarez, ${ }^{\mathrm{e}}$ and José Guadalupe Rutiaga-Quiñones ${ }^{\mathrm{a}, *}$
}

\begin{abstract}
This research characterized briquettes made with Pinus spp. sawdust without the use of additives. For this purpose, 19 samples of sawdust from different wood industries located in five states of the Mexican Republic were used. The densification process was carried out in a vertical hydraulic piston laboratory briquette machine. The briquettes were made with $40 \mathrm{~g}$ of sawdust, at $50^{\circ} \mathrm{C}, 20 \mathrm{kPa}$ and pressing for $5 \mathrm{~min}$. The results obtained varied as follows: moisture content (4.1\% to $7.2 \%)$, density (813.9 to $\left.1,014.4 \mathrm{~kg} / \mathrm{m}^{3}\right)$, volumetric expansion $(7.4 \%$ to $37.3 \%)$, compressive strength ( 4.9 to $40.8 \mathrm{~N} / \mathrm{mm})$, impact resistance index $(46.7 \%$ to $200 \%)$, ash $(0.1 \%$ to $1.1 \%)$, volatile matter $(82.9 \%$ to $90.7 \%)$, fixed carbon $(8.9 \%$ to $16.4 \%)$, and calorific value $(20.5$ to $22.8 \mathrm{MJ} / \mathrm{kg})$. The density of the briquettes was within the "acceptable" classification (800 to $1,200 \mathrm{~kg} / \mathrm{m}^{3}$ ). It was observed that, the higher the density, the lower the volumetric expansion, the higher the compressive strength, and the higher the impact resistance index. According to the ash content, the briquettes could achieve international quality. Due to high volatile matter values, rapid combustion of the briquettes with little generation of toxic smoke would be expected. Fixed carbon and calorific value results were acceptable.
\end{abstract}

Keywords: Bioenergy; Solid biofuels; Lignocellulosic waste; Proximate analysis; Calorific value

Contact information: a: Facultad de Ingeniería en Tecnología de la Madera, Edificio "D”, Ciudad Universitaria, Universidad Michoacana de San Nicolás de Hidalgo, Av. Fco. J. Múgica S/N, Col. Felicitas del Rio, Morelia, Michoacán, C. P. 58040, México; b: Instituto de Silvicultura e Industria de la Madera, Universidad Juárez del Estado de Durango, Boulevard del Guadiana No. 501, Ciudad Universitaria, Durango, Durango, C. P. 34120 México; c: Instituto de Estudios Ambientales, Universidad de la Sierra Juárez, Avenida Universidad S/N, Ixtlán de Juárez, Oaxaca, C.P. 68725 México; d: Insituto de Investigaciones Forestales, Agrícolas y Pecuarias, San Martinito, Km 56.5 Carretera Federal MéxicoPuebla, San Martinito, Municipio de Tlahuapan, Puebla, C. P. 74100 México; e: Facultad de Ciencias Agrícolas y Forestales, Universidad Autónoma de Chihuahua, Carretera Km 2.5 Delicias-Rosales, Cd. Delicias, Chihuahua, C. P. 33000 México; *Corresponding author: rutiaga@umich.mx

\section{INTRODUCTION}

The high dependence on fossil fuels in the world is well known, and the reserves of these non-renewable energy sources (crude oil, natural gas, and coal) are limited (Brožek et al. 2012). In recent years, renewable energies have proliferated as inexhaustible and environmentally friendly sources of energy, and their use is aimed at mitigating, among others, the environmental problems caused by the use of fossil fuels (González-Velasco 2009). Renewable energies include hydraulic energy, tidal energy, energy from waves, wind energy, geothermal energy, solar energy, and biomass (González-Velasco 2009; Velázquez-Martí 2018). Biomass is non-fossilized organic matter from two main sources: 
energy crops and residues or remains from human activities (Velázquez-Martí 2018). This residual lignocellulosic biomass can be transformed into solid biofuels (pellets or briquettes) (Velázquez-Martí 2018).

Biomass densification concentrates its chemical energy by converting it into solid biofuel. Industrial briquetting processes began in the mid- $19^{\text {th }}$ century (Carrillo-Parra et al. 2016). Briquettes have a variable shape; they are usually cylindrical or block, with or without a hole, which depends on the briquetting machine (Camps and Marcos 2008). They are substitutes for coal or firewood, and they can be used in the domestic or industrial sector for generation of heat or energy production, in boilers, ovens, stoves, chimneys, or gasifiers (Grover and Mishra 1996; Chen et al. 2009; Fonseca-Cuenca and Tierra-Tingo 2011).

Various investigations have evaluated the properties of briquettes made with different biomass residues: wheat straw and sawdust (Wamukonya and Jenkins 1995), woody materials (Li and Liu 2000), maize cob and coal (Wilaipon 2008), tree and shrub species (Kumar et al. 2011), wood residues (Paula et al. 2011), mixtures of different materials (mango leaves, acacia leaves, sawdust) and as an adhesive cow dung (Birwatkar et al. 2014), wood residues mainly from sawdust (Sánchez et al. 2014), tropical hardwood timber species (Mitchual et al. 2014), pine sawdust, recycled activated carbon and cassava starch (Ordoñez 2015), sawdust, bark, and wood-bark from Pinus montezumae, P. leiophylla, and P. pseudostrobus (Pérez-Pérez et al. 2016), different lignocellulosic biomass (Souza and Vale 2016), and fresh sawdust and weathered sawdust from Pinus pseudostrobus (Carrillo-Parra et al. 2018). Recently, briquettes have been made with sawdust and pine shavings using starch as an additive (Morales-Máximo et al. 2020). Brunerova et al. (2020) used larch sawdust, spruce shaving, and spent coffee grounds, in different proportions to make briquettes. Demirel et al. (2020) made briquettes using ground sunflowers stalks and hazelnut husks.

When briquettes are manufactured and commercialized, the amount of waste is reduced and also the volume transported; combustion is cleaner and more efficient (Chen et al. 2009; Gallipoliti et al. 2012). Biomass combustion has the potential to be $\mathrm{CO}_{2}$ neutral (Liu et al. 2014). With the biomass densification process, the energy value per unit volume of solid biofuel is increased (Karunanithy et al. 2012). Biomass energy is considered to have the greatest potential for renewable energy in the near future (Haobin et al. 2018). By using biomass or lignocellulosic waste as densified biofuels, it can bring benefits such as energy security, rural growth, and environmental protection (Carrillo-Parra et al. 2016).

The primary mechanical processing of wood generates a large volume of biomass (sawdust, bark, shavings, chips, and slabs) with a high degree of waste in Mexico (Zavala and Cortés 2000). These lignocellulosic wastes are usually improperly disposed of in the open air and are a source of contamination, although they can sometimes have local uses (Correa-Méndez et al. 2014). One possibility for the use of these lignocellulosic residues could be the production of densified biofuels, such as pellets and briquettes. Recent research carried out with pine sawdust has characterized the particle size, proximate analysis, ultimate analysis, and microanalysis of its ash (Rutiaga-Quiñones et al. 2020), in addition to results on its basic chemical composition (ash, extractives, holocellulose, and lignin) (Chávez-Rosales et al. 2021); these studies conclude that pine sawdust has the potential to make densified biofuels. No information was available on the characteristics and properties of the briquettes made at the laboratory level with sawdust from Mexican woods. Thus, the aim of this study was to produce briquettes at the laboratory level with pine sawdust collected in different forest industries and evaluate its physical, and energy 
properties. These properties are the main ones to consider as a preamble for a possible industrial scaling.

\section{EXPERIMENTAL}

\section{Origin of Raw Materials and Briquettes Production}

The collection of the lignocellulosic waste samples was carried out in different wood industries and forest ejidos (communal lands) in five states of the Mexican republic: Chihuahua (El largo, Agua azul, Grupo Gazo, and Multimaderas), Michoacán (Maderería Zamora, Maderas Preciosas Don Jesús, and Lázaro Cárdenas), Durango (Grupo Sezarik, Maderas y Tarimas Alba, Vencedores, La Cañita, and Pueblo Nuevo), Oaxaca (Unidad Comunal Forestal, Agropecuaria y de Servicios, Productora Comunal de Muebles Ixtlán, and Aserradero Mapsi), and Nuevo León (Maderas Los Pérez), and are the product of primary wood transformation of pine trees. Sawdust is the product of the primary transformation process of wood. It was collected without bark, and the original wood was not chemically treated. Because the wood is transported from the forest to the sawmill in a mixture of species, it was not possible to make a separation by pine species.

The moisture content of the sawdust ranged from $7.5 \%$ to $8.7 \%$ before the briquetting process. A vertical hydraulic piston laboratory briquetting machine (Lippel, Agrolândia, Brazil) was used to make the densified materials. The sawdust samples were used as they were collected in the forest industries, without separating by particle size. This was because their granulometric analysis had been carried out already, and it was found that the particle size distribution of this sawdust is suitable for the production of densified biofuels (Rutiaga-Quiñones et al. 2020). The briquetting conditions were temperature of $50{ }^{\circ} \mathrm{C}$, pressure of $20 \mathrm{MPa}$, and pressing time of $5 \mathrm{~min}$. No adhesive was used in the briquetting process. A total of 10 briquettes with a mass of $40 \mathrm{~g}$ were made for each type of biomass, and their average dimensions were $30 \mathrm{~mm}$ in diameter and $40 \mathrm{~mm}$ in length. The briquettes were conditioned at $20{ }^{\circ} \mathrm{C}$ and $50 \%$ relative humidity for seven days before determining their properties.

\section{Physical Properties}

The moisture content of the briquettes was determined by the UNE-EN 14774-1 (2010) standard. The density of each briquette was calculated by dividing the mass by its volume. The volumetric expansion of the briquettes was obtained from measuring the length and diameter of the briquette with an electronic vernier (Steren HER-411, Steren, Mexico City, Mexico). The measurement was carried out at two different times: immediately after the briquetting process and 7 days after conditioning in a climatic chamber with $50 \%$ relative humidity and $20{ }^{\circ} \mathrm{C}$. The volumetric expansion was calculated using the following equation (Oliveira et al. 2017),

$$
V E=\left[\left(V_{2}-V_{1}\right) / V_{1}\right] \times 100
$$

where $E V$ is volumetric expansion (\%), $V_{l}$ is volume of the briquette immediately after compaction $\left(\mathrm{cm}^{3}\right)$, and $V_{2}$ is volume of the briquette after the conditioning time $\left(\mathrm{cm}^{3}\right)$.

\section{Mechanical Properties}

The compressive strength in the briquettes was determined in a universal testing machine (Instron 300Dx, Instron, Norwood, Ma, USA), with a load capacity of $300 \mathrm{kN}$. 
The cross-head speed was $0.305 \mathrm{~mm} / \mathrm{min}$ (Mitchual et al. 2013). The briquette was placed horizontally in the compression tester, and the load was applied at a constant speed until the briquette failed by cracking. The impact resistance of the briquettes was determined by adapting the ASTM D 440-68 (2007) standard, and the impact resistance index was calculated according to the methodology proposed by Richards (1990).

\section{Proximate Analysis and Energy Production}

The ash content was obtained according to the UNE-EN 14775 (2010) standard, and the volatile matter according to the ASTM E872-82 (2013) standard. Fixed carbon was calculated by difference, subtracting the ash content, and the volatile content from 100 . The calorific value of the briquettes was determined according to the UNE-EN 14918 (2011) standard, using a semi-automatic calorimeter (LECO AC600, MI, USA). The energetic density was obtained by multiplying the average density by the average calorific value for each briquette.

\section{Statistical Analysis}

The tests of the briquettes were carried out in triplicate. In order to compare the results obtained, an analysis of variance was applied at $95 \%$ statistical confidence, and the mean values were compared by means of the multiple-range test with the least significant difference (LSD) method (Gutiérrez-Pulido and de la Vara-Salazar 2004). The results were analyzed using the Statgraphics Centurion program (Statgraphics Technologies, Inc., The Plains, VA, USA).

\section{RESULTS AND DISCUSSION}

\section{Physical Properties}

Significant statistical differences were found in the moisture content of the briquettes ( $p=0.0000)$ (Table 1, Fig. 1). The values obtained range from $4.1 \%$ (Sample 7) to $7.2 \%$ (Sample 18) (Table 1).

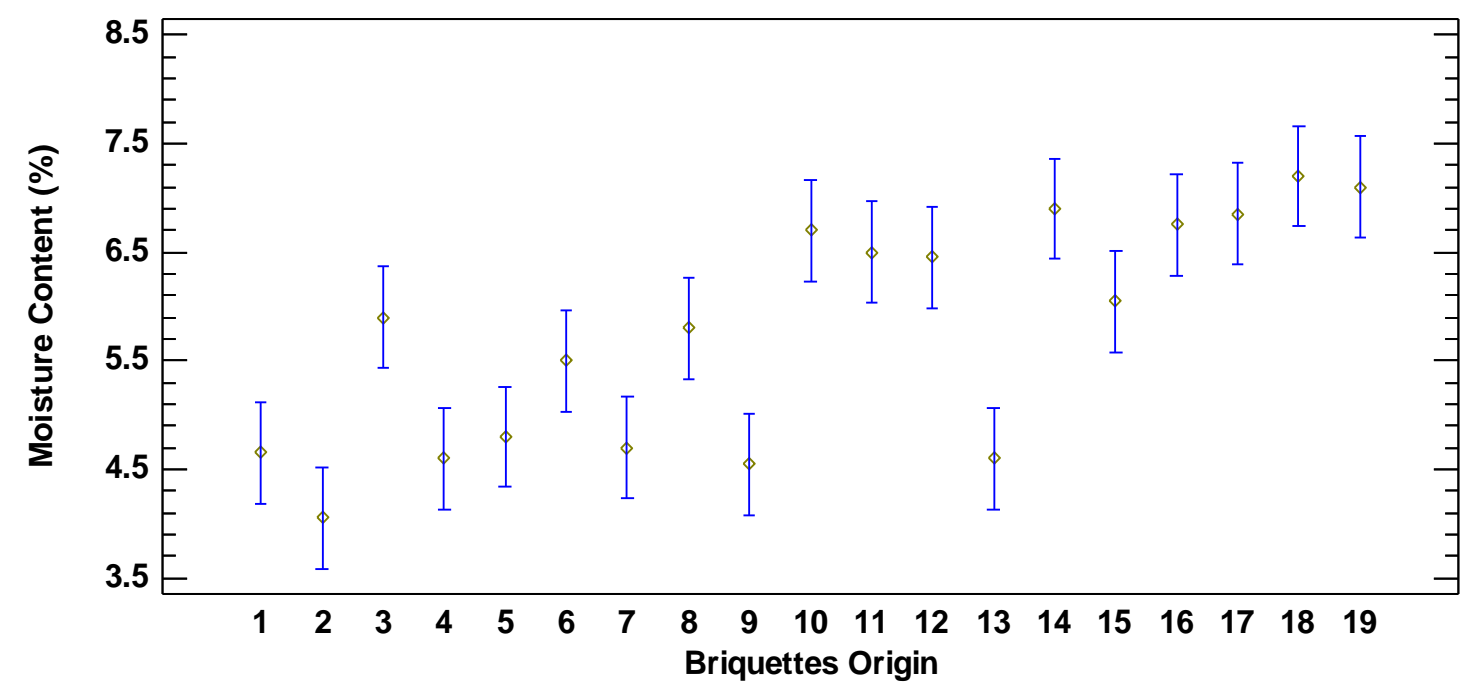

Fig. 1. Graphs of means for the moisture content of briquettes 
These moisture content values obtained here are low compared to the results of Gallipoliti et al. (2012), who in briquettes made with white pine sawdust remains plus a cassava starch binder report $12.3 \%$ moisture content. For their part, Sánchez et al. (2014) made briquettes from wood waste, mainly sawdust and reported $10 \%$ moisture content. In briquettes made with Pinus pseudostrobus sawdust, the moisture content ranged from $9.1 \%$ to $9.8 \%$ (Carrillo-Parra et al. 2018). The results are below the recommended value for briquettes ( $\leq 10 \%$, M10; $\leq 15 \%$, M15) according to the UNE-EN 14961-1 (2011) standard.

The density of the briquettes presents statistically significant differences ( $p=$ 0.0000 ) (Table 1, Fig. 2), and the results varied from $813.9 \mathrm{~kg} / \mathrm{m}^{3}$ (Sample 15) to $1,014.4$ $\mathrm{kg} / \mathrm{m}^{3}$ (Sample 9) (Table 1).

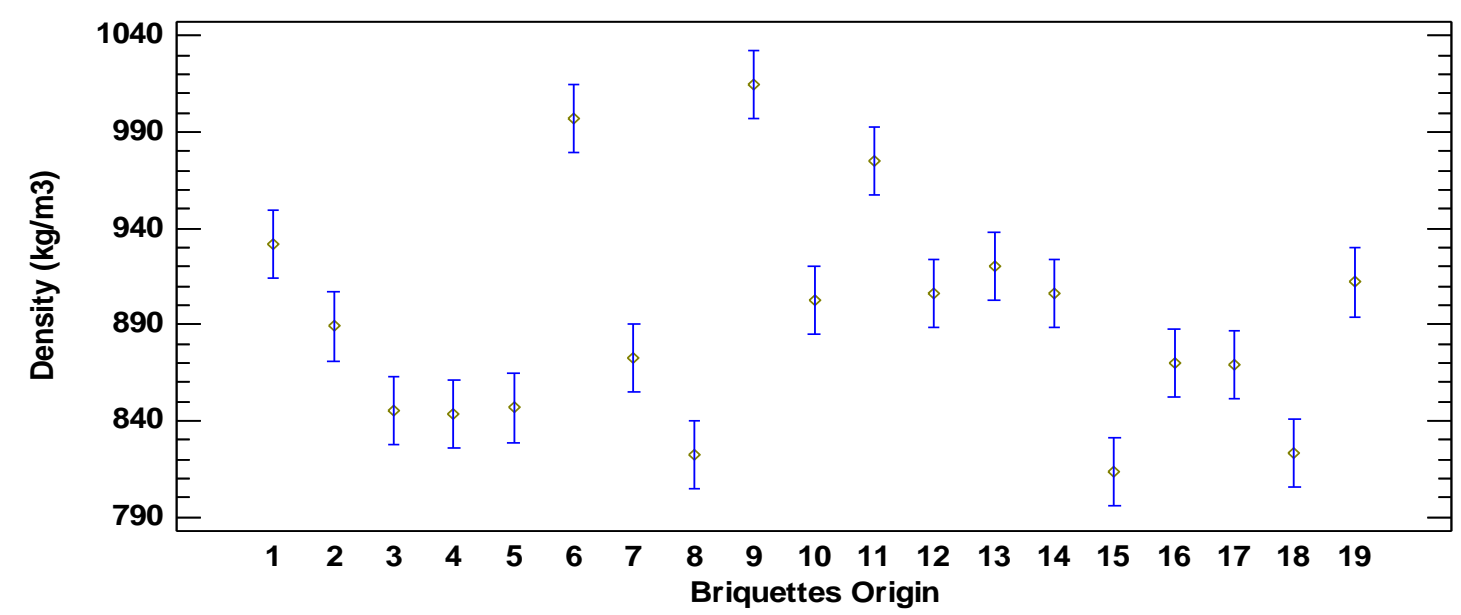

Fig. 2. Graphs of means for the density of briquettes

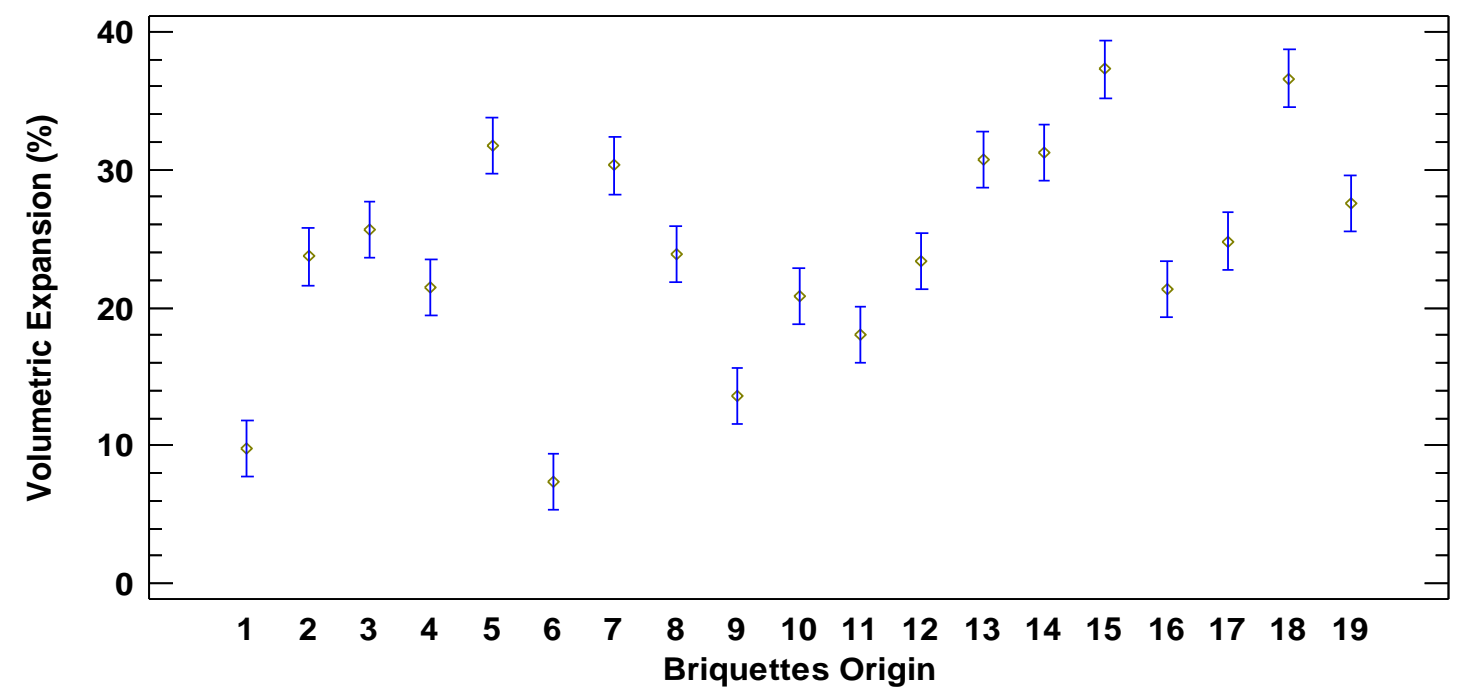

Fig. 3. Graphs of means for volumetric expansion of briquettes

The values found here are close to those reported for briquettes manufactured with wood waste ( 850 to $903 \mathrm{~kg} / \mathrm{m}^{3}$ ) (Paula et al. 2011), $\left(692.4\right.$ to $806.3 \mathrm{~kg} / \mathrm{m}^{3}$ ) (Brožek et al. 2012), with Pinus pseudostrobus sawdust $\left(<900 \mathrm{~kg} / \mathrm{m}^{3}\right)$ (Carrillo-Parra et al. 2018), but they are lower than the results reported for pine briquettes $\left(1,088\right.$ to $1,202 \mathrm{~kg} / \mathrm{m}^{3}$ ) (Souza 
and Vale 2016). However, even when the conditions of the briquetting process were modest, the quality of the briquettes was "acceptable", because they were in the range (800 to $1,200 \mathrm{~kg} / \mathrm{m}^{3}$ ) that corresponds to this classification indicated by Camps and Marcos (2008).

The volumetric expansion of the briquettes presents statistically significant differences ( $p=0.0000$ ) (Table 1, Fig. 2), with varied results, ranging from 7.4\% (Sample 6) to $37.3 \%$ (Sample 15) (Table 1). These values are high compared to the reported 2.2\% in sawdust briquettes and $2.9 \%$ in Pinus spp. ground sawdust briquettes (Oliveira et al. 2017), and could be explained due to the relatively low pressure and temperature used in the briquetting process. Previous studies suggest a volumetric expansion of $15 \%$ to $20 \%$ for a good briquette (Gonçalves et al. 2009). Bamgboye and Bolufawi (2009) mention that the increase in volume with fixed mass results in a reduction in density, a fact that was also observed here.

\section{Mechanical Properties}

The compressive strength of the briquettes ranged from $4.9 \mathrm{~N} / \mathrm{mm}$ (Sample 3 ) to $40.8 \mathrm{~N} / \mathrm{mm}$ (Sample 12) with statistically significant differences $(p=0.0000)$ (Table 1, Fig. $4)$. These values are lower than those obtained in fresh pine sawdust briquettes and in weathered pine sawdust briquettes (Carrillo-Parra et al. 2018), and in general are below the range ( 26.8 to $81.2 \mathrm{~N} / \mathrm{mm}$ ) reported for briquettes made with different wood waste (Brožek et al. 2012). These relatively low results could be explained by the modest conditions applied in the briquetting process. However, it was observed that at a higher density, the breaking force tends to be greater.

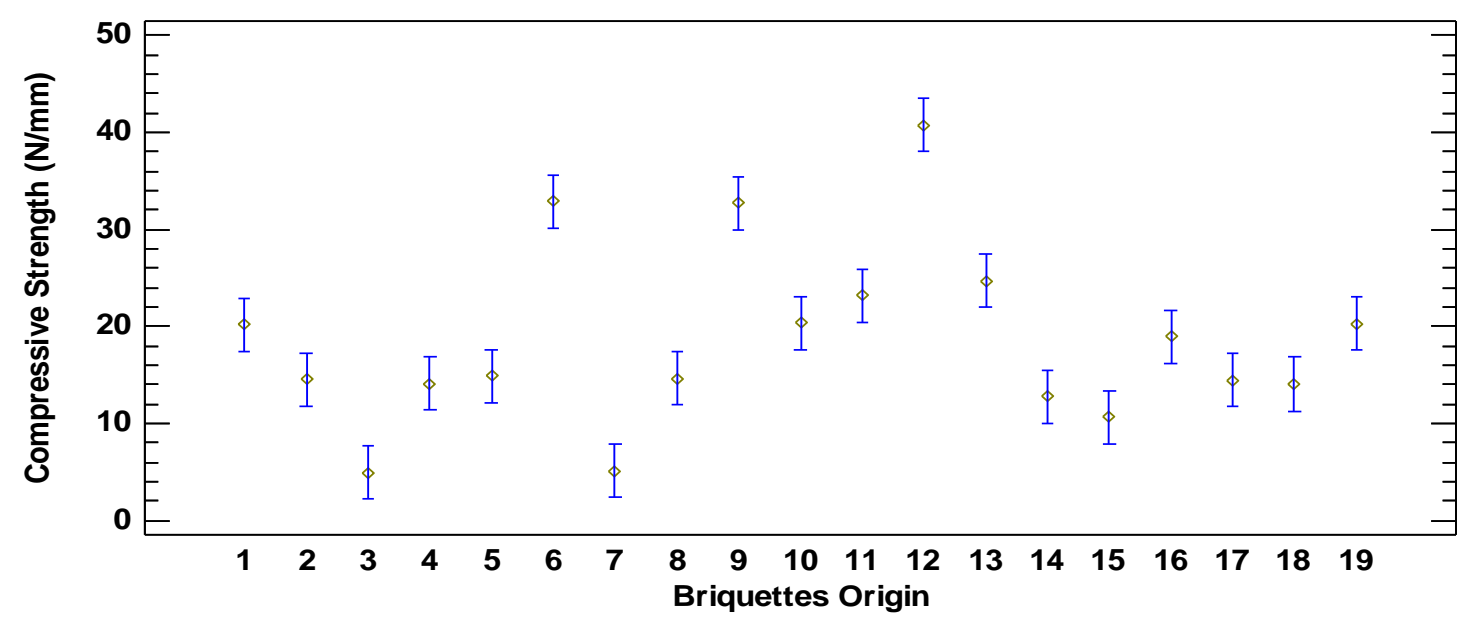

Fig. 4. Graphs of means for compressive strength of briquettes

Statistical significant differences were found in the impact resistance index of the briquettes $(p=0.0000)$ (Table 1 , Fig. 5). The results ranged from 46.7\% (Sample 8) to $200 \%$ (Sample 11), and are within the range $(25 \%$ to $200 \%)$ reported in briquettes of different woody materials ( $\mathrm{Li}$ and Liu 2000). As in the case of the compressive strength, it was observed that the higher the density, the greater the impact resistance. High impact resistance, and high compressive strength would be necessary to avoid damage when handling the briquettes. 


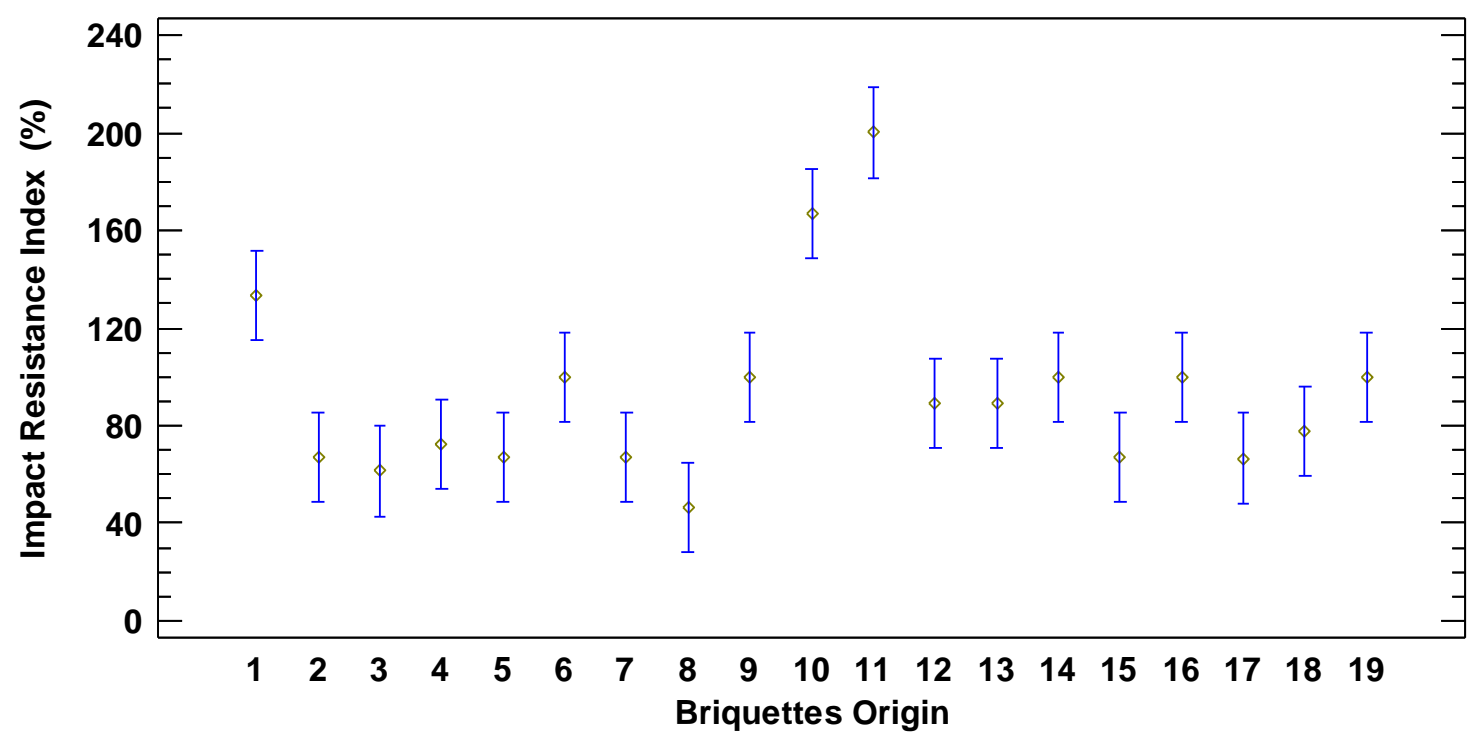

Fig. 5. Graphs of means for impact resistance index of briquettes

Table 1 summarizes the results of the physical and mechanical properties of the briquettes made with pine sawdust according to its origin.

Table 1. Physical and Mechanical Properties of Pinus spp. Sawdust Briquettes

\begin{tabular}{|c|c|c|c|c|c|c|}
\hline Sample & Origin & $\begin{array}{c}\text { Moisture } \\
\text { Content } \\
(\%)\end{array}$ & $\begin{array}{l}\text { Density } \\
\left(\mathrm{kg} / \mathrm{m}^{3}\right)\end{array}$ & $\begin{array}{c}\text { Volumetric } \\
\text { Expansión } \\
(\%)\end{array}$ & $\begin{array}{c}\text { Compressive } \\
\text { Strength } \\
(\mathrm{N} / \mathrm{mm})\end{array}$ & $\begin{array}{c}\text { Impact } \\
\text { Resistance } \\
\text { Index (\%) }\end{array}$ \\
\hline 1 & \multirow{4}{*}{ Chihuahua } & $4.65 \mathrm{a}$ & $931.99 \mathrm{f}$ & $9.76 \mathrm{~b}$ & $20.18 c$ & $133.33 \mathrm{e}$ \\
\hline 2 & & $4.05 \mathrm{a}$ & $889.03 \mathrm{c}$ & $23.68 d$ & $14.55 \mathrm{~b}$ & $67.00 \mathrm{~b}$ \\
\hline 3 & & $5.90 \mathrm{~b}$ & $845.12 \mathrm{a}$ & $25.69 \mathrm{e}$ & $4.93 \mathrm{a}$ & $61.33 \mathrm{~b}$ \\
\hline 4 & & $4.60 \mathrm{a}$ & $843.47 \mathrm{a}$ & $21.47 \mathrm{c}$ & $14.13 \mathrm{~b}$ & $72.33 \mathrm{~b}$ \\
\hline 5 & \multirow{5}{*}{ Michoacán } & $4.80 \mathrm{a}$ & $846.64 \mathrm{a}$ & $31.76 \mathrm{f}$ & $14.92 \mathrm{~b}$ & $67.00 \mathrm{~b}$ \\
\hline 6 & & $5.50 \mathrm{~b}$ & $996.89 \mathrm{~b}$ & $7.35 \mathrm{~b}$ & $32.93 \mathrm{f}$ & $100.00 \mathrm{~d}$ \\
\hline 7 & & $4.10 \mathrm{a}$ & $873.00 \mathrm{~b}$ & $30.29 \mathrm{f}$ & $5.14 \mathrm{a}$ & $67.00 \mathrm{~b}$ \\
\hline 8 & & $5.80 \mathrm{~b}$ & $822.27 \mathrm{a}$ & $23.86 \mathrm{~d}$ & $14.62 \mathrm{~b}$ & $46.67 \mathrm{a}$ \\
\hline 9 & & $4.55 \mathrm{a}$ & $1014.35 \mathrm{~h}$ & $13.56 \mathrm{~h}$ & $32.73 \mathrm{f}$ & $100.00 \mathrm{~d}$ \\
\hline 10 & \multirow{6}{*}{ Durango } & $6.70 \mathrm{c}$ & $902.34 \mathrm{c}$ & $20.83 c$ & $20.37 c$ & $166.67 \mathrm{f}$ \\
\hline 11 & & $6.50 \mathrm{c}$ & $974.75 \mathrm{~g}$ & $17.98 \mathrm{c}$ & $23.18 d$ & $200.00 \mathrm{f}$ \\
\hline 12 & & $6.45 \mathrm{c}$ & $906.36 \mathrm{~d}$ & $23.34 \mathrm{~d}$ & $40.79 \mathrm{~g}$ & $89.00 \mathrm{c}$ \\
\hline 13 & & $4.60 \mathrm{a}$ & $920.37 \mathrm{e}$ & $30.75 f$ & $24.71 \mathrm{e}$ & $89.00 \mathrm{c}$ \\
\hline 14 & & $6.90 \mathrm{~d}$ & $906.43 \mathrm{~d}$ & $31.23 \mathrm{f}$ & $12.80 \mathrm{~b}$ & $100.00 \mathrm{~d}$ \\
\hline 15 & & $6.05 \mathrm{~b}$ & $813.88 \mathrm{a}$ & $37.28 \mathrm{~g}$ & $10.66 \mathrm{~b}$ & $67.00 \mathrm{~b}$ \\
\hline 16 & \multirow{3}{*}{ Oaxaca } & $6.75 \mathrm{~d}$ & 869.64 b & $21.35 \mathrm{c}$ & $18.95 \mathrm{c}$ & $100.00 \mathrm{~d}$ \\
\hline 17 & & $6.85 \mathrm{~d}$ & $868.87 b$ & $24.82 d$ & $14.48 \mathrm{~b}$ & $66.67 \mathrm{~b}$ \\
\hline 18 & & $7.20 \mathrm{e}$ & $822.98 \mathrm{a}$ & $36.63 \mathrm{~g}$ & $14.06 \mathrm{~b}$ & $78.00 \mathrm{~b}$ \\
\hline 19 & $\begin{array}{l}\text { Nuevo } \\
\text { León }\end{array}$ & $7.10 \mathrm{e}$ & $911.95 \mathrm{e}$ & $27.51 \mathrm{f}$ & $20.25 \mathrm{c}$ & $100.00 \mathrm{~d}$ \\
\hline
\end{tabular}

\section{Proximate Analysis and Energy Production}

The ash content in the briquettes ranged from $0.1 \%$ (Sample 13) to $1.1 \%$ (Sample 15) with statistically significant differences $(p=0.0000)$ (Table 2, Fig. 6). These results are in agreement with the typical range $(0.1 \%$ to $1.0 \%)$ reported for the timber biomass of 
Pinus spp. by the UNE-EN 14961-1 (2011) standard, and they are also comparable with recent studies on various pine species (Bernabé-Santiago et al. 2013; Correa-Méndez et al. 2014; Pintor-Ibarra et al. 2017; Rutiaga -Quiñones et al. 2020). It is known that the concentration of inorganic substances in lignocellulosic biomass is an important factor for a solid biofuel (Obernberger and Thek 2010), and that it determines the amount of waste generated in the combustion process (Velázquez-Martí 2018). Due to the results obtained, briquettes with an ash content lower than $0.50 \%$ can achieve international quality (ÖNORM 7135 2000).

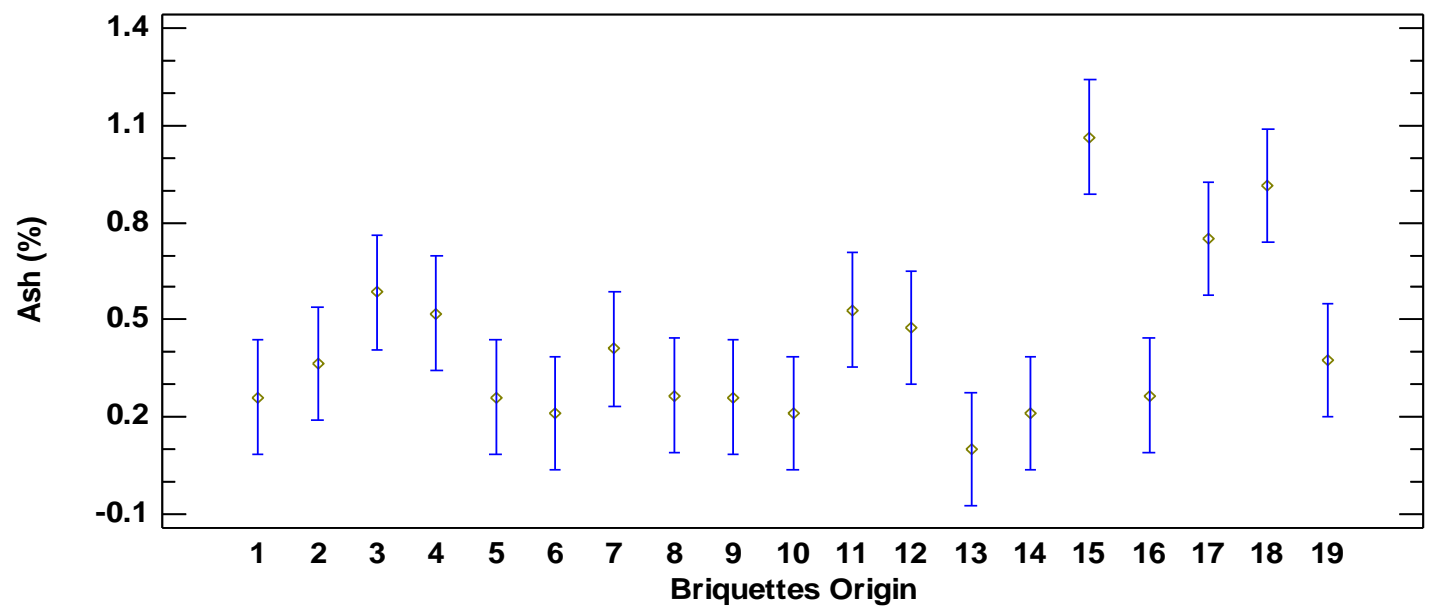

Fig. 6. Graphs of means for ash of briquettes

The amount of volatile matter in the briquettes ranged from $82.9 \%$ (Sample 18) to $90.7 \%$ (Sample 7) with statistically significant differences $(p=0.0000)$ (Table 2, Fig. 6). In general, these results coincide with the data previously reported for these biomass samples (Rutiaga-Quiñones et al. 2020).

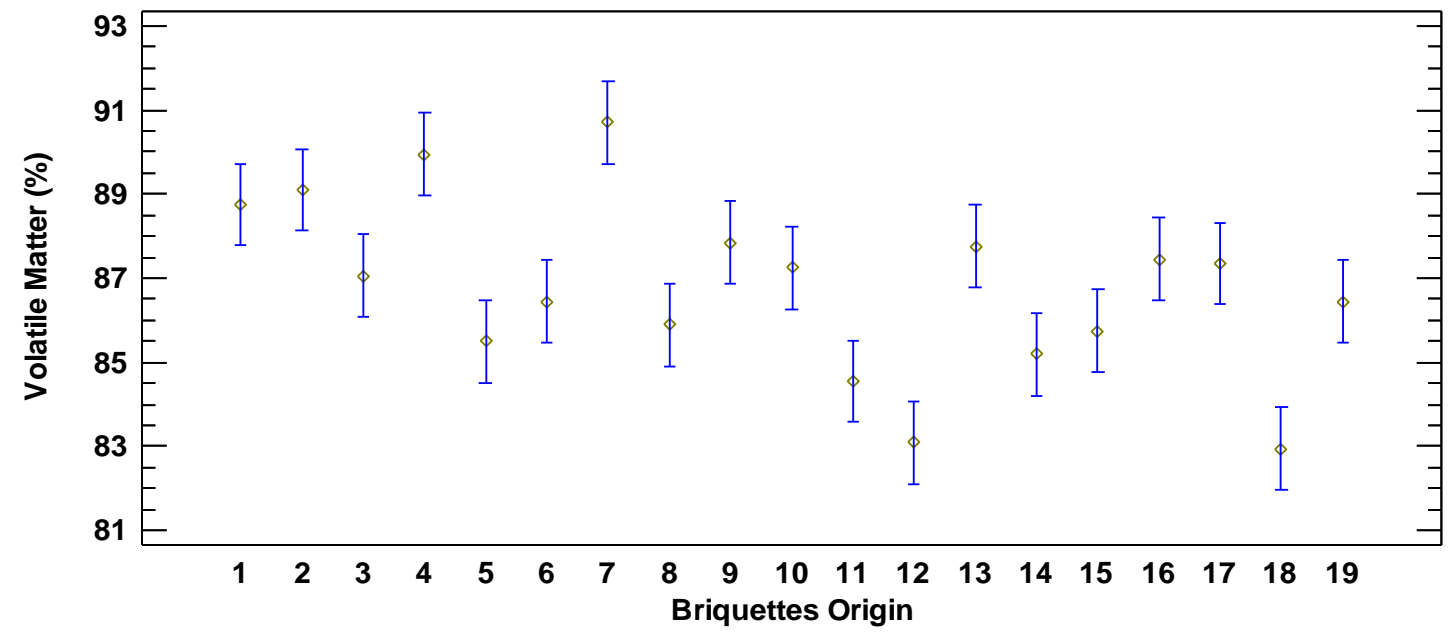

Fig. 7. Graphs of means for volatile matter of briquettes

Values reported for fresh pine sawdust briquettes range from $78.5 \%$ to $79.8 \%$, while when using weathered pine sawdust, the values found varied from $77.8 \%$ to $81.0 \%$ (Carrillo-Parra et al. 2018), these values are close to the lowest result found here. The range 
reported for biomass goes from $47.8 \%$ to $86.3 \%$ (Vassilev et al. 2010). The results are relatively high, and a rapid combustion of the briquettes would be expected, as high values of volatile matter produce rapid combustion of the material (Strehlow 1984), and when the material presents low values of volatile matter, smoke and toxic gases are produced (Van Loo and Koppejan 2008), so low environmental contamination would be expected when submitting these briquettes to a combustion process, minimizing the impact on ecosystems and even on human health (Querol 2008).

For the case of the fixed carbon content of the briquettes, the results presented statistically significant differences $(p=0.0000)$ (Table 2, Fig. 6) with values from $8.9 \%$ (Sample 7) to $16.4 \%$ (Sample 12). These results are generally close to the values previously reported for these sawdust samples (Rutiaga-Quiñones et al. 2020), and are located within the reported range (0.5\% to 37.9\%) for biomass (Vassilev et al. 2010). Carrillo-Parra et al. (2018) report values of $10.9 \%$ to $14.1 \%$ in fresh pine sawdust briquettes and values of $11.0 \%$ to $12.6 \%$ in briquettes made with weathered pine sawdust.

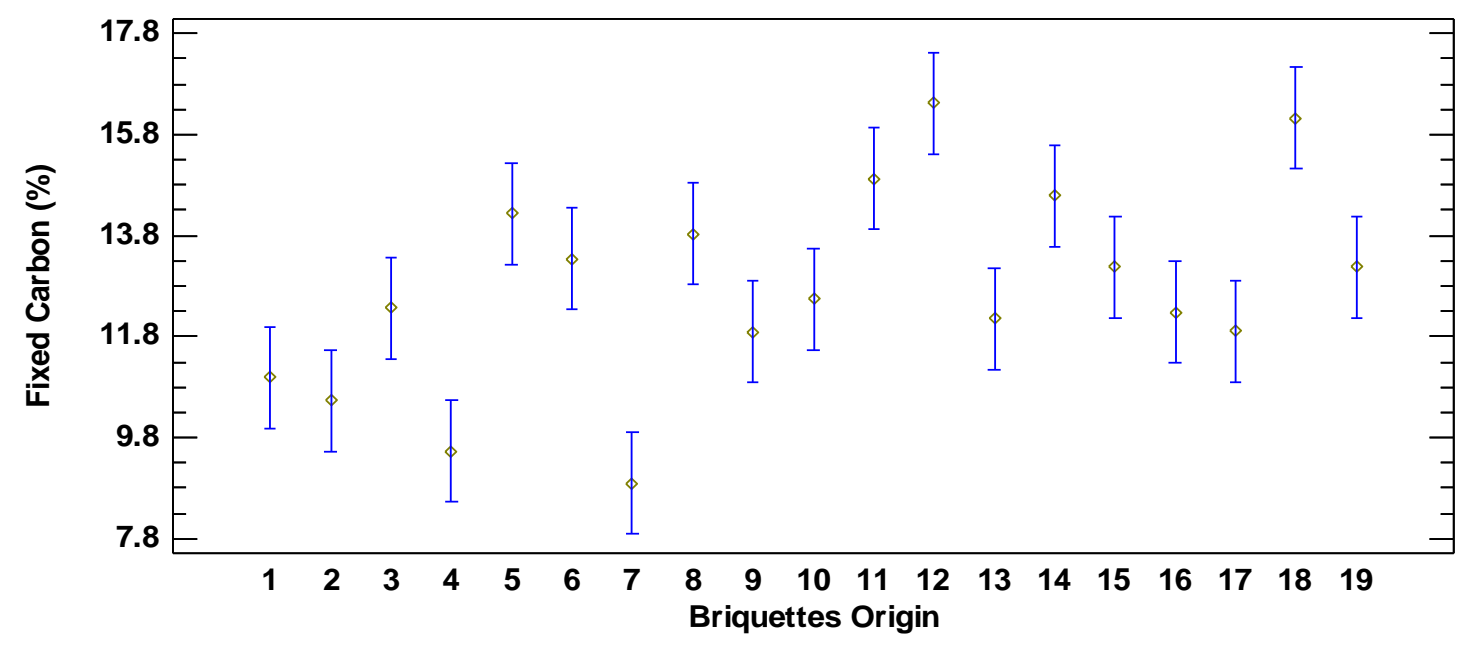

Fig. 8. Graphs of means for fixed carbon of briquettes

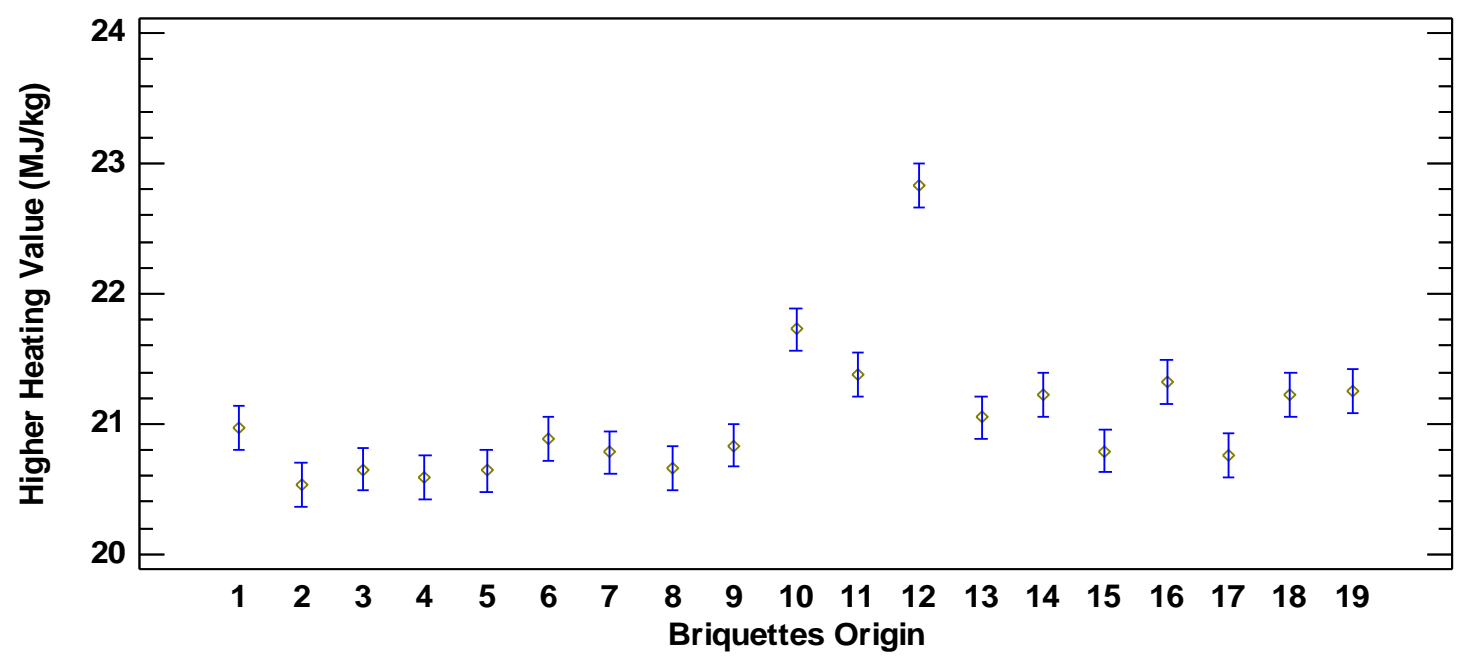

Fig. 9. Graphs of means for higher heating value of briquettes

The calorific value of the briquettes varied from $20.5 \mathrm{MJ} / \mathrm{kg}$ (Sample 2) to 22.8 $\mathrm{MJ} / \mathrm{kg}$ (Sample 12) with statistically significant differences $(p=0.0000)$ (Table 2, Fig. 6). 
These values determined here experimentally are higher than the results obtained for these same sawdust samples, using mathematical models based on the ultimate analysis (18.8 to $19.5 \mathrm{MJ} / \mathrm{kg}$ ), in the proximate analysis (18.8 to $20.7 \mathrm{MJ} / \mathrm{kg}$ ), ash content (19.2 to 19.9 $\mathrm{MJ} / \mathrm{kg}$ ) (Rutiaga-Quiñones et al. 2020), and chemical composition (20.1 to $21.0 \mathrm{MJ} / \mathrm{kg}$ ) (Chávez-Rosales et al. 2021). The present results were also higher than the typical values for coniferous woods (18.5 to $19.8 \mathrm{MJ} / \mathrm{kg}$ ) according to the UNE-EN 14961-1 (2011) standard, and are a consequence of the raw material used, mainly the amount of lignin $20.5 \%$ to $25.8 \%$ (Chávez-Rosales et al. 2021).

Table 2 summarizes the results of the proximate analysis and energy properties of the briquettes made with pine sawdust according to origin. The calculated energy density ranged from $16.9 \mathrm{GJ} / \mathrm{m}^{3}$ (Sample 15) to $21.1 \mathrm{GJ} / \mathrm{m}^{3}$ (Sample 9). Lower values were reported by Peng et al. (2015a), for white commercial wood pellet $\left(12.0 \mathrm{GJ} / \mathrm{m}^{3}\right)$, brown commercial wood pellets $\left(12.9 \mathrm{GJ} / \mathrm{m}^{3}\right)$, and pine woodchips $\left(11.8 \mathrm{GJ} / \mathrm{m}^{3}\right)$. The energy density strongly depends on the feedstock quality and the densification condition (Peng et al. 2015b).

Table 2. Proximate Analysis and Energy Production of Pinus Spp. Sawdust Briquettes

\begin{tabular}{|c|c|c|c|c|c|c|}
\hline Sample & Origin & $\begin{array}{l}\text { Ash } \\
(\%)\end{array}$ & $\begin{array}{c}\text { Volatile } \\
\text { Matter } \\
\text { (\%) }\end{array}$ & $\begin{array}{c}\text { Fixed } \\
\text { Carbon } \\
(\%)\end{array}$ & $\begin{array}{l}\text { Higher } \\
\text { Heating } \\
\text { Value } \\
(\mathrm{MJ} / \mathrm{kg})\end{array}$ & $\begin{array}{l}\text { Energy } \\
\text { Density } \\
\left(\mathrm{GJ} / \mathrm{m}^{3}\right)\end{array}$ \\
\hline 1 & \multirow{4}{*}{ Chihuahua } & $0.26 \mathrm{~b}$ & $88.75 \mathrm{c}$ & $10.99 \mathrm{~b}$ & $20.97 \mathrm{~b}$ & 19.5 \\
\hline 2 & & $0.37 \mathrm{~b}$ & $89.10 \mathrm{~d}$ & $10.54 \mathrm{a}$ & $20.53 a$ & 18.3 \\
\hline 3 & & $0.59 \mathrm{~d}$ & $87.05 \mathrm{c}$ & $12.37 \mathrm{c}$ & $20.65 a$ & 17.5 \\
\hline 4 & & $0.52 \mathrm{c}$ & $89.95 \mathrm{~d}$ & $9.53 \mathrm{a}$ & $20.59 a$ & 17.4 \\
\hline 5 & \multirow{5}{*}{ Michoacán } & $0.26 \mathrm{~b}$ & $85.50 \mathrm{~b}$ & $14.24 \mathrm{e}$ & $20.64 \mathrm{a}$ & 17.5 \\
\hline 6 & & $0.21 \mathrm{~b}$ & $86.45 \mathrm{~b}$ & $13.34 \mathrm{~d}$ & $20.89 \mathrm{~b}$ & 20.8 \\
\hline 7 & & $0.41 \mathrm{c}$ & $90.70 \mathrm{~d}$ & $8.89 \mathrm{a}$ & $20.78 \mathrm{a}$ & 18.1 \\
\hline 8 & & $0.27 \mathrm{~b}$ & $85.90 \mathrm{~b}$ & $13.84 \mathrm{~d}$ & $20.66 d$ & 17.0 \\
\hline 9 & & $0.26 \mathrm{~b}$ & $87.85 \mathrm{c}$ & $11.89 \mathrm{c}$ & $20.83 a$ & 21.1 \\
\hline 10 & \multirow{6}{*}{ Durango } & $0.21 \mathrm{~b}$ & $87.25 \mathrm{c}$ & $12.54 \mathrm{C}$ & $21.73 \mathrm{e}$ & 19.6 \\
\hline 11 & & $0.53 \mathrm{c}$ & $84.55 \mathrm{a}$ & $14.92 \mathrm{e}$ & $21.38 d$ & 20.8 \\
\hline 12 & & $0.48 \mathrm{c}$ & $83.10 \mathrm{a}$ & $16.43 \mathrm{f}$ & $22.84 \mathrm{f}$ & 20.7 \\
\hline 13 & & $0.10 \mathrm{a}$ & $87.75 \mathrm{c}$ & $12.15 \mathrm{c}$ & $21.05 c$ & 19.4 \\
\hline 14 & & $0.21 \mathrm{~b}$ & $85.20 \mathrm{~b}$ & $14.59 \mathrm{e}$ & $21.23 c$ & 19.2 \\
\hline 15 & & $1.07 \mathrm{f}$ & $85.75 \mathrm{~b}$ & $13.19 \mathrm{~d}$ & $20.79 \mathrm{a}$ & 16.9 \\
\hline 16 & \multirow{3}{*}{ Oaxaca } & $0.27 \mathrm{~b}$ & $87.45 \mathrm{c}$ & $12.29 \mathrm{c}$ & $21.32 \mathrm{c}$ & 18.5 \\
\hline 17 & & $0.75 \mathrm{e}$ & $87.35 \mathrm{c}$ & $11.90 \mathrm{c}$ & $20.76 \mathrm{a}$ & 18.0 \\
\hline 18 & & $0.92 \mathrm{e}$ & $82.95 \mathrm{a}$ & $16.14 \mathrm{f}$ & $21.22 \mathrm{c}$ & 17.5 \\
\hline 19 & $\begin{array}{l}\text { Nuevo } \\
\text { León }\end{array}$ & $0.38 \mathrm{~b}$ & $86.45 b$ & $13.18 \mathrm{~d}$ & $21.25 \mathrm{c}$ & 19.4 \\
\hline
\end{tabular}

\section{CONCLUSIONS}

1. Significant statistical differences $(p<0.05)$ were found in the results of the physical and energy evaluation of the briquettes that had been prepared using sawdust obtained from difference sources in Mexico. 
2. The density of the briquettes was within the "acceptable" classification $\left(800 \mathrm{~kg} / \mathrm{m}^{3}\right.$ to $\left.1,200 \mathrm{~kg} / \mathrm{m}^{3}\right)$.

3. The volumetric expansion was high, but the higher density was associated with a lower volumetric expansion.

4. The compressive strength and the impact resistance index were relatively low. Higher density increased these mechanical properties.

5. According to the ash content, the briquettes could achieve international quality.

6. Fixed carbon and calorific value results were acceptable.

7. In summary, the physical, mechanical, and energetic evaluation of the briquettes made at the laboratory level, with Pinus spp. sawdust, indicates that this lignocellulosic material is ideal for its densification at a possible industrial level, and its use represents a great potential to address the problems associated with the accumulation of waste in forestry industries whose storage represents environmental risks.

\section{ACKNOWLEDGMENTS}

The authors are grateful to the SENER-CONACYT (project: FSE-SENER-2014246911) for financial support. The authors also thank the companies and forest ejidos (communal lands) that donated the biomass samples.

This article is dedicated to Juan Ramos Quirarte on the occasion of his retirement as professor at the Universidad of Guadalajara (Mexico).

\section{REFERENCES CITED}

ASTM D440-68 (2007). "Standard test method of drop shatter test for coal," ASTM International, West Conshohocken, PA, USA.

ASTM E872-82 (2013). "Standard test method for volatile matter in the analysis of particulate wood fuels," ASTM International, West Conshohocken, PA, USA.

Bamgboye, A. I., and Bolufawi, S. J. (2009). "Physical characteristics of briquettes from Guinea corn (Sorghum bi-color) residue," Agricultural Engineering International: CIGR Journal XI; Manuscript 1364.

Bernabé-Santiago, R., Ávila-Calderón, L. E. A., and Rutiaga Quiñones, J. G. (2013). "Componentes químicos de la madera de cinco especies de pino del municipio de Morelia, Michoacán [Chemical components of the wood of five pine species from the municipality of Morelia, Michoacán]," Madera Bosques 19(2), 21-35. DOI: 10.21829/myb.2013.192338

Birwatkar, V. R., Khandetod, Y. P., Mohod, A. G., and Dhande, K. G. (2014). "Physical and thermal properties of biomass briquetted fuel," Ind. J. Sci. Res. Tech. 2(4), 55-62.

Brožek, M., Nováková, A., and Kolářová, M. (2012). "Quality evaluation of briquettes made from wood waste," Res. Agr. Eng. 58(1), 30-35. DOI: 10.17221/33/2011-RAE Brunerova, A., Roubík, H., Brožek, M., Haryanto, A., Hasanudin, U., Iryani, D. A., and Herák, D. (2020). "Valorization of bio-briquettes fuel by using spent coffe ground as an external additive," Energies 13(54), 1-15. DOI: 10.3390/en13010054 
Camps, M. M., and Marcos, M. F. (2008). Los Biocombustibles[Biofuels] ( ${ }^{\text {nd }}$ Ed.), Ediciones Mundi-Prensa, Madrid, Spain.

Carrillo-Parra, A., Contreras-Ortiz, E., Garza-Ocañas, F., Ngangyo-Heya, M., and Rutiaga-Quiñones, J. G. (2018). "Efecto de la intemperización y proceso en las características físicas, mecánicas y energéticas de briquetas [Weathering and process effects on physical, mechanical and energy characteristics of briquettes]," Revista Mexicana de Ciencias Forestales 9(50), 496-513. DOI: 10.29298/rmcf.v9i50.239

Carrillo-Parra, A., Contreras-Ortíz, E., Pérez-Pérez, E., Bustamante-García, V., CorralRivas, J. J., and Goche-Télles, J. R. (2016). "Briquetas [Briquettes]," in:

Biocombustibles Sólidos [Solid Biofuels], A. Carrillo-Parra and J. G. RutiagaQuiñones (eds.), Sierke-Verlag, Göttingen, Germany, pp. 138-159.

Chávez-Rosales, J. S., Pintor-Ibarra, L. F., González-Ortega, N., Orihuela-Equihua, R., Ruiz-Aquino, F., Luján-Álvarez, C., and Rutiaga-Quiñones, J. G. (2021). "Basic chemical composition of Pinus spp. sawdust from five regiones of Mexico, for bioenergetic purposes," BioResources 18(1), 816-824. DOI:

10.15376/biores.16.1.816-824

Chen, L., Xing, L., and Han, L. (2009). "Renewable energy from agro-residues in China: Solid biofuels and biomass briquetting technology," Renew. Sust. Energ. Rev. 13(9), 2689-2695. DOI: 10.1016/j.rser.2009.06.025

Correa-Méndez, F., Carrillo-Parra, A., Rutiaga-Quiñones, J. G., Márquez-Montesino, F., González-Rodríguez, H., Jurado-Ybarra, E., and Garza-Ocañas, F. (2014).

"Contenido de humedad y sustancias inorgánicas en subproductos maderables de pino para su uso en pélets y briquetas [Moisture and inorganic substance content in pine timber products for use in pellets and briquettes]," Rev. Chapingo Ser. Cie. 20(1), 7788. DOI: $10.5154 /$ r.rchscfa.2013.04.012

Demirel, C., Kagan Gürdil, G. A., Kabutey, A., and Herak, D. (2020). "Effects of forces, particle sizes, and moisture contents on mechanical behaviour of densified briquettes from ground sunflower stalks and hazelnut husks," Energies 13(2542), 1-19. DOI: 10.3390/en 13102542

Fonseca-Cuenca, E. G., and Tierra-Tingo, L. F. (2011). Desarrollo de un proceso tecnológico para la obtención de briquetas de aserrín de madera y cascarilla de arroz, y pruebas de producción de gas pobre [Development of a technological process to obtain wood sawdust and rice husk briquettes, and tests of lean gas production], Bachelor's Thesis, Escuela Superior Politécnica de Chimborazo, Riobamba, Ecuador.

Gallipoliti, V., Martina, P., Corace, J., Aeberhardt, R., and García Sola, E. (2012). Fabricación de briquetas con aserrín blanco de pino, análisis inmediato y obtención de su poder calorífico. Avances en Energías Renovables y Medio Ambiente (AVERMA) 16(06), 35-40.

Gonçalves, J. E., Sartori, M. M. P., and Leão, A. L. (2009). "Energia de briquetes produzidos com rejeitos de resíduos sólidos urbanos e madeira de Eucalyptus grandis [Energy from briquettes produced with waste from municipal solid waste and Eucalyptus grandis wood]," Rev. Bras. Eng. Agr. Amb. 13(5), 657-661.

González-Velasco, J. (2009). Energías Renovables [Renewable Energy], Editorial Reverté, Barcelona, Spain.

Grover, P., and Mishra, S. (1996). Biomass Briquetting: Technology and Practices (Field Document 46), Regional Wood Energy Development Programme in Asia, Food and Agriculture Organization of the United Nations, Bangkok, Thailand. 
Gutiérrez-Pulido, H., and de la Vara-Salazar, R. (2004). Análisis y Diseño de Experimentos [Analysis and Design of Experiments], McGrawHill, México, D. F., México.

Haobin, P., Li, Y., Li, Y., Yuan, F., and Chen, G. (2018). "Experimental investigation of combustion cinetics of wood powder and pellet," Journal of Combustion Article ID 5981598. DOI: $10.1155 / 2018 / 5981598$

Karunanithy, C., Wang, Y., Muthukumarappan, K., and Pugalendhi, S. (2012). "Physiochemical characterization of briquettes made from different feedstocks," Biotechnology Research International Article ID 165202. DOI: 10.1155/2012/165202

Kumar, J. I. N., Patel, K., Kumar, R. N., and Bhoi, R. K. (2011). "An evaluation of fuelwood of some Aravally mountain tree and shrub species of Western India," Biomass Bioenerg. 35(1), 411-414. DOI: 10.1016/j.biombioe.2010.08.051

Li, Y, and Liu, H. (2000). "High-pressure densication of wood residues to form an upgraded fuel," Biomass Bioenerg. 19(3), 177-186. DOI: 10.1016/S09619534(00)00026-X

Liu, Z., Fei, B., Jiang, Z., and Liu, X. (2014). "Combustion characteristics of bamboobiochars,” Bioresource Technol. 167, 94-99. DOI: 10.1016/j.biortech.2014.05.023

Mitchual, S. J., Frimpong-Mensah, K., and Darkwa, N. A. (2013). "Effect of species, particle size and compacting pressure on relaxed density and compressive strength of fuel briquettes," International Journal of Energy and Environmental Engineering 4(30), 1-6. DOI: 10.1186/2251-6832-4-30

Mitchual, S. J., Frimpong-Mensah, K., and Darkwa, N. A. (2014). "Evaluation of fuel properties of six tropical hardwood timber species for briquettes," Journal of Sustainable Bioenergy Systems 4(01), 1-9. DOI: 10.4236/jsbs.2014.41001

Morales-Máximo, M., Ruíz-García, V.M., López-Sosa, L. B., and Rutiaga-Quiñones, J. G. (2020). "Exploitation of wood waste of Pinus spp. for briquette production: A case study in the community of San Francisco Pichátaro, Michoacán, Mexico," Appl. Sci. 10, 2933; DOI:10.3390/app10082933

Obernberger, I., and Thek, G. (2010). The Pellet Handbook, Earthscan, London, England.

Oliveira, L. H., Barbosa, P. V. G., Lima, P. A. F., Yamaji, F. M., and Júnior, C. R. S. (2017). "Aproveitamento de resíduos madeireiros de Pinus sp. com diferentes granulometrias para a produção de briquetes [Use of wood residues of Pinus sp. with different granulometry to briquettes production]," Revista de Ciências Agrárias 40(3), 683-691. DOI: 10.19084/RCA17010

ÖNORM M 7135 (2000). "Compressed wood or compressed bark in natural state-pellets and briquettes, requirements and test specifications," Österreichisches Normungsinstitut [Austrian Standards Institute], Vienna, Austria.

Ordoñez-Rivera, O. F. (2015). Evaluación de la influencia de la formulación de combustibles sólidos densificados de aserrín de pino blanco (Pinus pseudostrobus Lindl), reciclado de carbón activado y almidón de yuca (Manihot esculenta), sobre las propiedades fisicoquímicas y fisicomecánicas de los combustibles sólidos densificados en general [Evaluation of the influence of the formulation of densified solid fuels of white pine sawdust (Pinus pseudostrobus Lindl), recycled activated carbon and cassava starch (Manihot esculenta), on the physicochemical and physicomechanical properties of densified solid fuels in general], Bachelor's Thesis, Universidad de San Carlos de Guatemala, Guatemala.

Paula, L. E. de R. e, Trugilho, P. F., Rezende, R. N., Assis, C. O., and Baliza, A. E. R. (2011). "Produção e avaliação de briquetes de resíduos lignocelulósicos [Production 
and evaluation of lignocellulosic waste briquettes]," Pesquisa Florestal Brasileira 31(66), 103-112. DOI: 10.4336/2011.pfb.31.66.103

Peng, J., Bi, X. T., Lim, C. J., Peng, H., Kim, C. S., Jia, D., and Zuo, H. (2015b).

"Sawdust as an effective binder for making torrefied pellets," Appl. Energ. 157, 491498. DOI: 10.1016/j.apenergy.2015.06.024

Peng, J., Wang, J., Bi, X. T., Lim, C. J., Sokhansanj, S., Peng, H., and Jia, D. (2015a). "Effects of thermal treatment on energy density and hardness of torrefied wood pellets," Fuel Process. Technol. 129, 168-173. DOI: 10.1016/j.fuproc.2014.09.010

Pérez-Pérez, J. E., Carrillo-Parra, A., Rutiaga-Quiñones, J. G., Bustamante-García, V., and Garza-Ocañas, F. (2016). "Efecto del tipo de material, presión y temperatura en la densidad de briquetas de residuos industriales de tres especies del género Pinus [Effect of the type of material, pressure and temperature on the density of industrial waste briquettes of three species of the genus Pinus]," Revista Ciencia Nicolaita 68: 80-89.

Pintor-Ibarra, L. F., Carrillo-Parra, A., Herrera-Bucio, R., López-Albarrán, P., and Rutiaga-Quiñones, J. G. (2017). "Physical and chemical properties of timber byproducts from Pinus leiophylla, P. montezumae and P. pseudostrobus for a bioenergetic use," Wood Res. 62(6), 849-861.

Querol, X. (2008). “Calidad del aire, partículas en suspensión y metales [Air quality, suspended particles and metals]," Revista Española de Salud Pública 82(5), 447-454. DOI: $10.1590 / \mathrm{S} 1135-57272008000500001$

Richards, S. R. (1990). "Physical testing of fuel briquettes," Fuel Process. Technol. 25(2), 89-100. DOI: 10.1016/0378-3820(90)90098-D

Rutiaga-Quiñones, J. G., Pintor-Ibarra, L. F., Orihuela-Equihua, R., González-Ortega, N., Ramírez-Ramírez, M. A., Carrillo-Parra, A., Carrillo-Ávila, N., Navarrete-García, M. A., Ruíz-Aquino, F., Rangel-Méndez, J. R., Hernández-Solís, J. J., and LujánÁlvarez, C. (2020). "Characterization of Mexican waste biomass relative to energy generation,” BioResources 15(4), 8529-8553. DOI: 10.15376/biores.15.48529-8553

Sánchez, E. A., Pasache, M. B., and García, M. E. (2014). "Development of briquettes from waste wood (sawdust) for use in low-income households in Piura, Peru," in: Proceedings of the World Congress on Engineering, London, UK, pp. 2-4.

Souza, F. de, and Vale A. T. do. (2016). "Densidade energética de briquetes de biomassa lignocelulósica e sua relação com os parâmetros de briquetagem [Energy density of lignocellulosic biomass briquettes and their relationship with briquetting parameters]," Pesquisa Florestal Brasileira 36(88), 405-413. DOI: 10.4336/2016.pfb.36.88.879

Strehlow, R. A. (1984). Combustion Fundamentals, McGraw-Hill, Inc., New York, USA. UNE-EN 14774-1 (2010). "Determinación del contenido de humedad, Método de secado en estufa. Parte 1: Humedad total [Determination of moisture content. Method of oven drying. Part 1: Total humidity]," Asociación Española de Normalización y Certificación (AENOR), Madrid, Spain.

UNE-EN 14775 (2010). "Método para la determinación del contenido en cenizas [Method for the ash content determination]," Asociación Española de Normalización y Certificación (AENOR), Madrid, Spain.

UNE-EN 14918. 2011. "Determinación del poder calorífico [Determination of calorific value]," Asociación Española de Normalización y Certificación (AENOR), Madrid, Spain. 
UNE-EN 14961-1 (2011). "Especificaciones y clases de biocombustibles. Parte 1: Requisitos generales [Specifications and classes of biofuels. Part 1: General requirements]," Asociación Española de Normalización y Certificación (AENOR), Madrid, Spain.

Van Loo, S., and Koppejan, J. (2008). The Handbook of Biomass Combustion and CoFiring, Taylor \& Francis, New York, USA.

Vassilev, S. V., Baxter, D., Andersen, L. K., and Vassileva, C. G. (2010). “An overview of the chemical composition of biomass," Fuel 89(5), 913-933. DOI: 10.1016/j.fuel.2009.10.022

Velázquez-Martí, B. (2018). Aprovechamiento de la Biomasa para uso Energético [Exploitation of Biomass for Energy Use] (2nd Ed.), Editorial Reverté, Barcelona, Spain.

Wamukonya, L., and Jenkins, B. (1995). "Durability and relaxation of sawdust and wheat-straw briquettes as possible fuels for Kenya," Biomass Bioenerg. 8(3), 175179. DOI: 10.1016/0961-9534(95)00016-Z

Wilaipon, P. (2008). "Density equation of bio-coal briquettes and quantity of maize cob in Phitsanulok, Thailand," American Journal of Applied Sciences 5(12), 1808-1811. DOI: 10.3844/ajassp.2008.1808.1811

Zavala, D. Z., and Cortés, R. H. (2000). “Análisis del rendimiento y utilidad del proceso de aserrío de trocería de pino [Analysis of the performance and utility of the pine log sawing process]," Madera Bosques 6(2), 41-55. DOI: 10.21829/myb.2000.621374

Article submitted: December 16, 2020; Peer review completed: January 24, 2021; Revised version received and accepted: January 30, 2021; Published: February 2, 2021. DOI: 10.15376/biores.16.2.2249-2263 